\title{
Implementasi Prinsip Yakin pada Rukun Iman dalam Konseling Islam
}

\author{
Jarnawi $^{*}$, Azhari ${ }^{2} \&$ Adzanmi Urka ${ }^{3}$ \\ ${ }^{123}$ Program Studi Bimbingan Konseling Islam, Fakultas Dakwah dan Komunikasi , UIN Ar- \\ Raniry, Banda Aceh \\ *Email : jarnawi.m.nurishaq@gmail.com
}

\begin{abstract}
ABSTRAK
Penelitian ini bertujuan untuk mengetahui implementasi prinsip yakin pada rukun iman dalam konseling Islam. Jenis penelitian ini adalah penelitian pustaka (library research), dengan menggunakan (content analysis) yang bersifat pembahasan terhadap isi suatu informasi tertulis yaitu menganalisa temuan dan pembahasan hasil penelitian yang berkaitan dengan implementasi prinsip yakin dalam Islam, dan implementasi prinsip yakin pada rukun iman dalam konseling Islam. Selanjutnya prinsip yakin menurut ajaran Islam yaitu harus mencakup empat syarat, yaitu; sabar, tawakal, ridha, dan takwa (takut) untuk mencapai ilmul yakin, ainul yakin, dan haqqul yakin didukung dengan cara berkontemplasi (merenung), mentadaburi Al-Quran, berdoa, dan khalwat. Implemantasi prinsip yakin pada rukun iman dalam konseling Islam menanamkan keyakinan pada konseli bahwasanya ada Allah yang memeberikan ketenangan seperti rasa aman dari ketakutan dan yang mengenyangkan dari rasa lapar.
\end{abstract}

Kata Kunci : Implementasi; Yakin; Rukun Iman; Konseling Islam;

\section{ABSTRACT}

This research aims to know the implementation of the belief principle in Islamic counseling. Using content analysis, this library research is a division between the contents of written information, namely analyzing the findings and division of research results related to the implementation of a particular principle in Islam and the implementation of a particular principle based on faith in Islamic counseling. Moreover, there shall be four conditions in Islam: patience, laughter, joy, and fear, that they may attain the knowledge of certainty, and that they may be supported in repentance, and that they may follow it, and that they may pray, and that they may beware. The implementation of the principle believes in the prayer of faith in the council of Islam convinces the council that God gives tranquility like a sense of security from fear and enlightenment from bunger.

Keywords : Implementation; Certainly; Hand of Faith; Islamic Konseling.

Diterima: Juli 2020. Disetujui: Agustus 2020. Dipublikasikan: September 2020. 
Jarnawi., Azhari., A, Urka.

\section{PENDAHULUAN}

Kewajiban manusia terhadap Allah sebagai hamba diimplementasikan melalui ruang syariat Islam di mana dalam ruang tersebut tertuang dan menjadi panduan terhadap pokok-pokok ajaran dalam agama. Oleh karana itu, tidak ada manusia yang mengaku beragama tanpa ia meyakini apa yang ditetapkan oleh agama tersebut. Dalam Islam, terdapat pilar-pilar keimanan yang dipahami dalam rukun iman sebanyak enam pilar keimanan yang termasuk salah satu dasar dari agama. Keenam pilar tersebut adalah beriman terhadap hal-hal yang "ghaib" yang hanya dapat diyakini secara transedental. Selain itu, dengan enam rukun iman ini maka semua manusia akan lebih paham tentang hal yang harus diimani (dipercaya). Sebagaimana firman Allah SWT yang artinya: "Wabai orang-orang yang beriman, tetaplah beriman kepada Allah dan rasul-Nya dan kepada Kitab yang Allah turunkan kepada rasul-Nya serta Kitab yang Allah turunkan sebelumnya. Barangsiapa yang kafir kepada Allah, malaikat-malaikat-Nya, kitab-kitab-Nya, rasul-rasul-Nya, dan hari kemudian, maka Sesungguhnya orang itu telah sesat sejauh-jaubnya" (Q.S. An-Nisa':136).

Kandungan ayat tersebut menjelaskan ada enam rukun iman, yaitu iman kepada Allah dan malaikat-malaikat-Nya, kitab-kitab-Nya, rasul-rasul-Nya, dan hari kemudian (kiamat). Rukun iman yang keenam adalah iman kepada takdir baik dan buruk, sebagaimana sabda Rasulullah SAW yang artinya: "Engkau beriman kepada Allah, malaikat-malaikat-Nya, rasul-rasul-Nya, dan Hari Akhir dan engkau beriman pada takdir yang baik maupun yang buruk" (H.R. Bukhari R.A.).

Dengan demikian, rukun iman terdiri atas: 1) Iman kepada Allah 2) Iman kepada para malaikat 3) Iman kepada kitab Allah 4) Iman kepada para rasul 5) Iman kepada hari kiamat 6) Iman kepada takdir baik dan buruk. Menjalani kewajiban sebagai makhluk tentu setiap manusia tidak pernah lepas dari masalah. W. Winkel sebagaimana yang dikutip oleh Mulyadi "masalah adalah sesuatu yang menghambat, merintangi, dan mempersulit dalam usahanya untuk menggapai sesuatu" (Mulyadi, 2016). Oleh sebab itu, para ahli di tanah air yang memiliki semangat (ghirah) membantu mensejahterakan masyarakat melalui layanan konseling telah merintis jalan guna memperoleh model konseling yang mampu menjawab berbagai persoalan secara tuntas (Sutoyo, 2014).

Layanan konseling Islami merupakan suatu proses pemberian bantuan pengarahan atas diri konseli dengan membangkitkan daya ruhiniah dan kinerja sistem ruhiniahnya, untuk meningkatkan kesehatan jiwa dan menurut ajaran Islam guna mencapai kualitas hidup yang diridhai Allah (Yusuf, 2012). Selain itu Diniaty (2013) menyebutkan bahwa konseling dalam perspektif Islam dapat diartikan sebagai bagian dari ibadah atau amal yang harus dilakukan umat muslim untuk mendapatkan kedekatan dengan khaliknya. Dalam pelaksanaan konseling Islam perlu memperhatikan asas-asas yang berkenaan dengan nilai-nilai penting yang berlandaskan tauhid dan dilengkapi dengan pedoman hidup yang sempurna, yakni 
Implementasi Prinsip Yakin pada Rukun Iman dalam Konseling Islam Al-Quran dan Al-Hadits sehingga dapat dijadikan pedoman dalam kehidupan. Tehnik yang bisa digunakan oleh konselor muslim dalam proses konseling juga tidak jauh berbeda ketika Nabi SAW melaksanakan dakwah, yaitu bil hikmah, mavidloh khasanah dan mujadalah (Diniaty, 2013). Meskipun tergolong sebagai fenomena baru, sesungguhnya konseling Islam sama tuanya dengan kegiatan dakwah Islam di tengah-tengah masyarakat. Ini tidak lain karena konseling pada hakikatnya merupakan bagian penting dari kehidupan beragama itu sendiri (Abdurrahman, 2019). Selanjutnya, prinsip dasar bimbingan dan konseling Islami adalah prinsip-prinsip yang terkandung dalam ajaran agama Islam, dalam AlQuran dan Sunnah Rasul (Siregar, 2015).

Saling percaya antara konselor dan konseli, karena konselor maupun konseli akan melaksanakan hak dan kewajibannya sebagaimana mestinya sehingga konseling akan berjalan dengan lancar. Akan tetapi, meskipun manusia telah dilengkapi dengan berbagai potensi, manusia tetaplah memiliki keterbatasan, maka di sinilah peran konselor untuk membantu konseli menggunakan pendekatan islami, dengan menyadarkan konseli bahwasanya ada Allah S.W.T. yang akan selalu mengawasinya, membantunya, dan memberi rasa aman padanya. Sebagaimana firman Allah SW'T yang artinya: "yang telah memberi makanan kepada mereka untuk menghilangkan lapar dan mengamankan mereka dari ketakutan" (Q.S. Quraisy: 4). Sesuai dengan nilai-nilai keimanan yang dipegang umat Islam, konseling bertujuan menanamkan nilai-nilai tersebut pada klien dalam menyikapi masalahnya (Diniaty, 2013).

Yakin dalam ajaran Islam tidak sama dengan dogma atau persangkaan tetapi harus melalui ilmu, pemahaman dan kesaksian. Karena seluruh kehidupan Muslim bepusat dan dibentuk oleh-Nya. Iman adalah pokok pangkal dalam sistem kehidupan muslim secara keseluruhan dan tauhid bagaikan cahaya keilahian yang menerangi di kegelapan, jika sekedar percaya kepada Allah tanpa menumbuhkan sifat-sifat mengagungkan tuhan di dalam dirinya, tentu kualiatas motivasi manusia akan lebih renda ketika tuhan tidak lagi menjadi pusat orientasinya. Dampak ideal dari keyakinan seseorang terhadap ajaran Islam adalah dirinya merasakan kehadiran Allah dalam kehidupan dan mengantarkanya pada suatu keyakinan bahwa ia merasa diawasi oleh tuhannya maka pada saat yang sama ia juga percaya bahwa dirinya dalam liputan kasih sayang dan meyakini sepenuhnya bahwa seluruh proses kehidupan termasuk permasalahan merupakan kehendak Allah.

Namun dalam kenyataannya semuanya tidak seperti yang diharapkan, banyak di antara Muslim mengalami permasalahan yang pada akhirnya membuat dirinya tidak tenang dalam menjalani kehidupan. Sutoyo (2017) menyebutkan bahwa konseling bukan sekedar apa yang diucapkan konselor, tetapi lebih dari itu adalah apa yang dilakukan konselor dalam kehidupan sehari-hari. Karakteristik pribadi tercermin dalam keikhlasan, ketulusan, kehangatan, dan sikap yang menyenangkan dalam memberikan layanan kepada konseli. Karakteristik tersebut 
Jarnawi., Azhari., A, Urka.

akan lebih kokoh manakala dilandasi dengan iman yang benar dan kokoh pula.

Adapun penelitian-penelitian terdahulu yang pernah dilaksanakan belum ada yang membahas mengenai implementasi yakin di rukun Iman dalam konseling Islam. Seperti penelitian yang berjudul Nilai-Nilai dan Makna Bimbingan Konseling Islam dalam Hadis Sahih Bukhārī (Zulfa, 2017). Penelitian ini mengungkapkan bahwa Nilai-nilai bimbingan dan konseling Islam yang terkandung dalam hadis Sahih Bukhārī di antaranya nilai aqīdah, syariat, social/muamalah, dan akhlak yang bermuara pada akhlāq al-karīmah, dengan terbentuknya insan muttaqīn. Selanjutnya Zulfa (2017) mengungkapkan bahwa terdapat makna bimbingan dan konseling Islam yang terkandung dalam rukun Islam, yaitu bimbingan/tuntunan/arahan, petunjuk, pencegahan, pemberian bantuan, terarah, sistematis, pemahaman, pengentasan, pengembangan/peningkatan, fitrah beragama, dan selaras.

Penelitian yang dilakukan oleh Khirzani, Effendi dan Mujib (2019) mengenai Bimbingan Agama dalam Meningkatkan Pemahaman Ketauhidan Remaja fokus pada bimbingan keagamaan. Hasil penelitian ini mengungkapkan bahwa tingkat pemahaman santri di Ponpes Tanjung Salam yang meliputi pemahaman tentang dua kalimat syahadat, sifat-sifat Allah, dan rasul-Nya meningkat setelah mengikuti bimbingan agama berupa kajian kitab kuning (tijan ad-darory fi syarbil badjury). Pemahaman tersebut dibarengi dengan kesadaran untuk mengaplikasikannya diaplikasikan dalam kehidupan mereka.

Selanjutnya penelitian yang dilakukan oleh Kamaruzzaman (2014) mengenai Model Bimbingan Kelompok Berbasis Rukun Iman untuk Mencegah Kenakalan Remaja. Penelitian ini ditemukan bahwa model bimbingan kelompok berbasis rukun iman efektif untuk mencegah kenakalan remaja yang dibuktikan dengan uji hipotesis yang menunjukkan bahwa semua indikator kecenderungan kenakalan remaja mengalami penurunan signifikan setelah mendapatkan intervensi bimbingan kelompok berbasis rukun Iman.

Berangkat dari latar belakang di atas dan penelitian-penelitian terdahulu yang belum mengungkapkan prinsip yakin pada rukun Iman dalam Konseling Islam ini, maka peneliti terdorong untuk mengkaji dan memahami Kembali implementasi prinsip yakin dalam ruang konseling Islam yang dituangkan pada penelitian ini dan berjudul "Implementasi Prinsip Yakin pada Rukun Iman dalam Konseling Islam".

\section{LANDASAN TEORITIS}

Yakin artinya merasa pasti atau rasa kepastian. Pengetahuan dengan rasa pasti terhadap sesuatu. Kebalikan dari yakin adalah syakk (syak, rasa kurang percaya. Al-Jurjani, ahli bahasa Arab dan teologi, dalam karyanya At-Ta'rifat (defenisidefenisi) menuturkan bahwa beberapa defenisi yakin, antara lain: "Kemantapan qalbu terhadap suatu objek, penglihatan gaib, penglihatan mata hati dengan cahaya 
Implementasi Prinsip Yakin pada Rukun Iman dalam Konseling Islam iman, dan pengetahuan yang diperoleh setelah kesangsian". Al-Junaidi al-Bagdadi mengatakan bahwa yakin adalah mantapnya pengetahuan sehingga orang yang memilikinya tidak ingin berpaling dan berubah haluan (Mujieb, 2009).

Derajat yakin menurut Syadzi (2012) terdiri dari tiga tingkatan yaitu (1) Ilmul Yakin adalah sesuatu yang tampak dari kebenaran, serta menerima sesuatu yang tidak tampak dari kebenaran dan bersandar pada sesuatu yang hadir dari kebenaran. Adapun yang tampak dari kebenaran tersebut adalah segala perintah Allah dan larangan-Nya, yang tak tampak berupa beriman kepada yang ghaib, seperti percaya kepada surga, neraka, (2) Ainul Yakin adalah keyakinan yang sampai pada derajat ini tidak lagi memerlukan bukti. (3) Haqqul Yakin adalah derajat para utusan Allah S.W.T. Nabi Muhammad S.A.W. dengan kedua matanya melihat langsung surga dan neraka, bagi kita, haqqul yakin kita rasakan di saat akhirat (Syadzi, 2012).

Prinsip yakin (1) Sabar: Secara bahasa Sabar berarti 'tertahan'. Secara istilah sabar berarti menahan lisan dari mengeluh, menahan hati dari marah, dan menahan anggota badan dari menampakkan kemarahan. (2) Tawakal: Tawakal adalah amalan hati, berupa meninggalkan dorongan hawa nafsu disertai dengan penyerahan daya dan kekuatan hanya kepada Allah S.W.T. dengan memutuskan ketergantungan hati dengan selain Allah. (3) Ridha: Ridha adalah hilangnya perasaan sedih terhadap hukum apapun yang terjadi dan menyambutnya dengan kegembiraan, serta tenangnya hati dengan pilihan Allah S.W.T. kepada hambaNya. Sebab, Allah telah memilahkan yang terbaik baginya (Syadzi, 2012). (4) Takwa (takut): Takwa adalah sesuatu yang sangat erat hubunganya dengan keyakinan, yaitu tekad yang keras dalam hati untuk tidak mekukan dosa, dan kebencian terhadap perbuatan durhaka kepada Allah. (Al-Ghazali, 2017).

Implementasi Menuju yakin (Al-Ghazali, 2017) di antaranya: (1) Berkontemplasi (Merenung): Berkontemplasi maksudnya adalah hendaknya seorang merenung untuk mengintropeksi diri sendiri, membayangkan kehidupan akhirat, serta melepaskan diri dari kehidupan dunia sejenak. Para ulama menghabiskan waktu untuk merenungi akhirat. (2) Mentadaburi Al-Quran: Tadabur dalam bahasa Arab berarti mengetahui pungkasan sesuatu. Adapun yang dimaksud tadabur disini adalah menyelami kandungan makna ayat-ayat Al-Quran sehingga sampai kepada maksud, tujuan, dan sesuatu yang diinginkan dari kita. Dengan mengetahui tafsir, membaca dengan pelan, memperindah suara saat membaca, menghindari hal yang menghalangi pemahaman, dan mengulang-ulang sebahagian ayat maka tanpa ini, Al-Quran takubahnya seperti buku pelajaran ataupu, buku sastra karya manusia lainya. (3) Berdoa adalah cara mengetuk semua pintu untuk mencari kenyakinan dalam menempuh jalan Allah. Dialah yang menghunjamkan kenyakinan kedalam hati orang-orang shaleh sebelumsebelumnya. (4) Khalwat: Ibnu Al-Jauzi berkata, "Khalwat adalah jaring untuk memburu ketenangan batin. 
Jarnawi., Azhari., A, Urka.

Iman menurut bahasa berasal dari kata amana yuminu fabua mu'minun, berarti 'kepercayaan'. Sedangkan menurut istilah berarti kepercayaan kepada Allah S.W.T., para malaikat-Nya, kitab-kitab-Nya, para utusan-utusan-Nya, hari kiamat, dan qada-qadar (ketentuan) baik serta buruk semua datang dari Allah (Mujieb, 2009). Dalam hal ini Rasulullah S.A.W. bersabda: "Iman adalah pengakuan dengan lisan, pembenaran dengan hati, dan pembuktian dengan amal perbuatan". Selaras dengan pendapat Syaikhul Islam Ibnu Taimiah, Beliau berkata bahwa: "Iman adalah ucapan dan perbuatan, maka termasuk ke dalam ucapan adalah ucapan hati dan lisan sekaligus. Inilah yang dipahami dari lafazh Al-Qaul (ucapan) dan Al-Kalam (pembicaraan). Tidak berbeda dengannya jika disebutkan secara mutlak, karena ucapan yang mutlak dan perbuatan yang mutlak adalah mengucap ucapan hati dan lisan serta perbuatan hati dan anggota badan." Iman adalah jaminan yang paling kuat dan kokoh dalam menghadapi kekuatan dan kekecewaan dalam pasang surutnya kehidupan. Orang-orang yang beriman tidak berputus asa atau kehilangan kepercayaan diri dalam pasang situasi dan kondisi apapun. Sebab mereka tahu bahwa diri mereka terikat dengan kekuatan dan kekuasaan yang tak terbatas dari sang pencipta alam semesta. Mereka selalu ingat kepada-Nya dan dilindungi oleh-Nya dalam semua keadaan hati mereka senang tiasa tenang, jernih, dan kuat (Latif, 2011).

Unsur-Unsur Rukun Iman: kesatu, Iman Kepada Allah: Kata Allah berasal dari bahasa Arab yang terdiri dari empat huruf, yaitu alif, lam, lam, dan ha. Kata Allah tidak memiliki bentuk mutsannah (dual) maupun jama' (prular). Berbeda dengan kata ilah, ia memiliki bentuk ganda, yaitu ilahaini (dua tuhan), bentuk jamaknya alihah (tuhan-tuhan). Oleh karena itu kata Allah dikhususkan hanya kepada Allah, Dzat Yang Maha Esa, tidak ada sekutu bagi-Nya (Ilmi, 2012). Seorang Muslim beriman kepada Allah dalam arti, dia menyakini bahwasanya Allah memiliki Asmaul Husna dan segala sifat kesempurnaan-Nya yang suci dari kekurangan. Kedua, Iman Kepada Para Malaikat: Kata 'malaikat' berasal dari bahasa Arab, yaitu malaikah. Malaikat adalah bentuk jamak dari kata masdar AlMulukah yang berarti $A r$-Risalah (misi atau pesan). Secara istilah malaikat makhluk gaib yang diciptakan oleh Allah S.W.T. dari cahaya dengan sifat-sifat tertentu. AlJurjani mendefinisikan malaikat dengan "jasad halus yang dicipta oleh Allah dari cahaya dengan bermacam bentuk” (Ilmi, 2012). Seorang Muslim beriman kepada malaikat-malaikat Allah. Dengan meyakini bahwa mereka juga ciptaan Allah yang paling mulia.

Ketiga, Iman Kepada Kitab-Kitab Allah: Kitab berasal dari bahasa Arab, dengan akar kata ka-ta-ba yang berarti 'menulis'. Dengan itu maka kitab berarti 'tulisan', bentuk jamaknya adalah kutub dalam bahasa Indonesia, kitab sering disamakan dengan buku Secara istilah, yang dimaksud kitab adalah kitab suci yang diturunkan Allan S.W.T. kepada para nabi dan rasul-Nya. Al-Quran Al-Karim adalah kitab teragung dari kitab-kitab lainnya dan penyempurna semua ajaran dan 
Implementasi Prinsip Yakin pada Rukun Iman dalam Konseling Islam hukum yang ada pada kitab-kitab sebelumnya. Keempat, Iman Kepada Para Rasul: Kata Nabi berasal dari kata na-ba yang berarti 'ditinggikan', atau dari kata naba-a yang artinya 'berita' jadi, Nabi adalah seseorang yang ditinggikan derajatnya oleh Allah S.W.T. dengan memberinya wahyu. Adapun Rasul berasal dari kata arsala yang artinya 'mengutus'. Rasul berarti 'yang diutus' jadi, rasul adalah seorang yang diutus oleh Allah S.W.T. untuk menyampaikan misi ajaran (risalab). Adapun sifat wajib bagi nabi dan rasuladalah: Shidiq (benar). Mustahil para rasul berkata dusta (kadzib). Amanah (dipercaya) mustahil para rasul berkhianat (khiyanah) melanggar, atau melalaikan amanah yang diembannya. Tabligh (menyampaikan). Mustahil menyembunyikan (kitman) perintah atau ajaran yang diperintahkan Allah SWT. Fathanah (cerdas) mustahil baginya (jablun) bodoh.

Kelima, Iman Kepada Hari Kemudian (Kiamat): Hari akhir adalah peristiwa berakhirnya kehidupan dunia yang fana, berlanjut ke kehidupan yang kekal (akhirat). Sebagai mukmin harus percaya pada datangnya hari akhir tersebut. Seorang Muslim beriman bahwasanya kehidupan dunia ini mempunyai saat-saat di mana dia akan berakhir dan memiliki hari terakhir yang tiada sesudahnya, lalu datang kemudian kehidupan berikutnya untuk kehidupan akhirat. Semua mahkluk dibangkitkan kembali untuk diadilkan perhitungan (bisab) di mana orang saleh diberi balasan kenikmatan abadi di dalam surga, sedangkan orang-orang yang durhaka (penuh dosa) diganjar dengan azab dan siksaan menhinakan di neraka.

Keenam, Iman Kepada Qadha dan Qadar: Rukun Iman yang terakhir adalah memercayai qadha dan qadar, yang sering disebut juga takdir. Qadha berasal dari kata qadha yang artinya 'kehendak atau ketetapan hukum'. Adapun qadar berasal dari kata qadara yang artinya 'ketentuan atau ukuran' (Ilmi, 2012). Para ulama berbeda pendapat tentang perbedaan antara kedua istilah tersebut, sebagian mengatakan bahwa qadar adalah kententuan Allah sejak zaman azali (zaman yang tak ada awalnya), sedangkan qadha' adalah ketetapan Allah terhadap sesuatu pada waktu terjadi. Jadi, ketika Allah menetapkan sesuatu akan terjadi pada waktunya, ketentuan ini disebut qadar. Kemudian ketika telah tiba waktu yang telah ditetapkan pada masa tersebut, ketentuan ini disebut qadha', sebagian ulama mengatakan bahwa kedua istilah tersebut mempunyai satu makna. Pendapat yang dianggap rajih (unggul/kuat) adalah bahwa kedua istilah tersebut bila dikumpulkan (qadar-qadha'), maka mempunyai makna berbeda, tapi bila dipisahkan antara satu dengan yang lain maka mempunyai makna yang sama (Ilmi, 2012).

Prayitno mengemukakan "Konseling adalah proses pemberian bantuan yang dilakukan melalui wawancara konseling oleh seorang ahli (konselor) kepada individu yang sedang mengalami sesuatu masalah (konseli) yang bermuara pada teratasinya masalah yang dihadapi konseli." (Prayitno dan Emran, 1994). Konseling juga dapat diartikan sebagai hubungan timbal balik antara dua individu dimana yang seseorang sebagai konselor berusaha membantu individu yang lain yaitu konseli untuk mencapai pengertian tentang dirinya sendiri dalam hubungan 
Jarnawi., Azhari., A, Urka.

dengan masalah-masalah yang dihadapinya pada masa yang akan datang. Menurut Blocher, dalam Shertzer dan Stone, Sebagaimana dikutip oleh prayitno mengemukakan bahwa: "Konseling adalah membantu individu agar dapat menyadari dirinya sendiri dan memberikan reaksi terhadap pengaruh-pengaruh lingkungan diterimanya, selanjutnya membantu yang bersangkutan menentukan beberapa makna pribadi tingkah laku tersebut dan mengembangkan serta memperjelas tujuan-tujuan dan nila-nilai untuk perilaku di masa yang akan datang" (Prayitno dan Emran, 1994).

Konseling Islam bertujuan menjadikan konseli dapat berdiri sendiri dan tidak tergantung pada konselor, konseli yang dibimbing setelah dibantu diharapkan dapat mandiri dengan ciri-ciri pokok mampu mengenal diri sendiri dan lingkunganya. Tanggungjawab dan konseling Islam bertujuan agar konseli mencapai kehidupan berdaya guna untuk diri, keluarga, bangsanya dan agar meningkatkan keimanan dan ketakwaan konseli terhadap Allah sehingga konseli menjadi manusia yang seimbang antara pengembangan intelektual, sosial, emosional, dan religious (Willis, 2009). Sebagaimana yang pernah di sampaikan oleh Sutoyo (2014) yang merupakan arah yang dituju adalah pengembangan fitrah atau kembali kepada fitrah. Berdasarkan kutipan di atas dapat dipahami tujuan dari konseling Islam ialah suatu proses pelayanan bantuan yang diberikan oleh konselor kepada konseli untuk mambantu konseli agar mampu memahami pribadinya sehingga konseli mencapai kehidupan yang lebih berguna terhadap keluarga dan lingkungannya agar meningkatkan keimanan kepada Allah dan kesadaran konseli untuk berubah menjadi pribadi yang mandiri.

\section{HASIL DAN PEMBAHASAN}

\section{Prinsip yakin dalam Islam}

Prinsip yakin ini mendasarkan pada Al-Quran, Al-Hadis dan dilengkapi dengan pendapat para ulama. Adapun prinsip-prinsip yakin yang dimaksud meliputi sabar, bertawakal, ridha dan takwa (Syadzi, 2012).

Pertama, Sabar. Sabar adalah suatu pengorbanan untuk sesuatu yang kita sukai, yang berharga demi menggapai suatu hal yang ditetapkan Allah tanpa disertai keluh kesah dan tetap dalam kondisi tegar. Sabar merupakan kemampuan mengendalikan diri yang juga dipandang sebagai sikap yang mempunyai nilai tinggi dan mencerminkan kekokohan jiwa orang yang memilikinya. Sebagaimana firman Allah SW'T dalam surah Al-Baqarah: 153. Adapun bentuk-bentuk sabar adalah sebagai berikut. Sabar dalam ketaatan sebagaimana firman Allah yang artinya: "Hai orang-orang yang beriman, bersabarlah kamu dan kuatkanlah kesabaranmu dan tetaplah bersiap siaga (di perbatasan negerimu) dan bertakwalah kepada Allah, supaya kamu beruntung" (Q.S. Ali Imran: 200). Selanjutnya Sabar dalam meninggalkan maksiat. Sebagaimana firman Allah yang artinya: Dan orang-orang yang sabar dalam kesempitan, penderitaan dan dalam peperangan. Mereka itulah 
Implementasi Prinsip Yakin pada Rukun Iman dalam Konseling Islam

orang-orang yang benar (imannya); dan mereka Itulah orang-orang yang bertakwa" (Q.S. Al-Baqarah: 177). Selanjutnya Sabar dalam menghadapi cobaan. Sebagaimana Allah SWT berfirman: yang artinya: "Mereka Itulah orang yang dibalasi dengan martabat yang Tinggi (dalam syurga) karena kesabaran mereka dan mereka disambut dengan penghormatan dan Ucapan selamat di dalamnya" (Q.S. Al-Furqan: 75).

Kedua, Tawakal. Tawakal adalah amalan hati, berupa meninggalkan kemauan dan dorongan hawa nafsu disertai dengan penyerahan daya dan kekuatan hanya kepada Allah dengan memutuskan ketergantungan hati dengan selain Allah. Ketiga, Ridha. Ridha adalah hilangnya perasaan sedih terhadap hukum apapun yang terjadi dan menyambutnya dengan kegembiraan, serta tenangnya hati dengan pilihan Allah SWT kepada hamba-Nya. Sebab, Allah telah memilahkan yang terbaik baginya. Menurut Syadzi (2012) hubungan ridha dan yakin sangatlah erat." Sebab, bagaimana mungkin orang yang yakin tidak ridha dengan ketentuan Allah. Allah S.W.T. yang maha Penyayang yang sayang-Nya kepada hamba-Nya melebihi sayangnya seorang ibu kepada anaknya. Baginya tidak ridha orang yang meyakini bahwa Allah Mahatahu maslahat (kebaikan) dan madarat (kerusakan) bagi hambNya seorang hamba tidak mengetahunya kecuali sesuatu yang ada di bawah kakinya. Bagaimana tidak ridha orang yang yakin bahwa Allah S.W.T. Maha Pengasih, yang mengasihi hamba-Nya dengan kenikmatan yang tak terhitung".

Keempat, Takwa (takut). Takwa adalah sesuatu yang sangat erat hubungan dengan keyakinan yaitu tekad yang keras dalam hati untuk tidak melakukan dosa, dan kebencian terhadap perbuatan durhaka kepada Allah" (Syadzi, 2012). Maka bisa disimpulkan dari kutipan di atas jika keyakinan sudah benar-benar nyata di dalam hati maka ketakutan kepada Allah juga akan benar-benar nyata di dalamnya, ibarat selembar kertas yang tidak terpisahkan antara sisi satu dan sisi lainya.

\section{Implementasi Prinsip Yakin pada Rukun Iman dalam Konseling Islam}

Yakin dalam ajaran Islam tidak sama dengan dogma atau persangkaan tetapi harus melalui ilmu dan pemahaman. Karena seluruh kehidupan muslim bepusat dan dibentuk oleh-Nya. Sebagaimana yang dicontohkan Abu Muslim Al-Khaulani, beliau pernah berkata di hadapan para peyakin yang kukuh. Ketika beliau ditanyakan, "bagaimana jika anda tidak bisa menikmati dari sebagian yang anda lakukan?" beliau menjawab: " Manusia tidak akan menjadi peyakin sejati sampai mampu menjiwai makna keyakinan kedalam hatinya, yang meliputi: keyakinan terhadap Al-Qur'an, Al-Hadis, kematian, keyakinan terhadap kuasa Allah, keyakinan terhadap ketetapan Allah, yang mencakup rezeki dan ajal, serta yakin dengan sifat dan nama-nama Allah."

Berdasarkan uraian di atas maka dapat dipahami bahwa Allah adalah Tuhan semesta alam ini yang memiliki segala yang dibutuhkan oleh manusia. Yakin beriman kepada Allah berarti harus yakin kepada malaikat-malaikat-Nya, kitabkitab-Nya, para-rasul-Nya, hari kiamat-Nya, dan pada qada-qadar yang telah 
Jarnawi., Azhari., A, Urka.

ditetapka-Nya. Dalam konseling islam, implementasi prinsip yakin di antaranya: Yakin bahwa Allah ada dengan segala sifat dan nama-nama baik-Nya: Yakin beriman kepada Allah terhadap nama-nama baiknya dibagi menjadi dua bagian; dengan ucapan dan dengan tindakan. Adapun nama-nama Allah yang di yakini dengan tindakan, seperti Al-Ahad, Al-Muta'al, dan Al-Qadir maka diwajibkan untuk mengakuinya dan tunduk di sampingnya.

Selain itu, Allah juga memiliki nama-nama yang dianjurkan untuk dilaksanakan kandungan maknanya, seperti Ar-Rahim, Al-Karim, dan Al-Afwu. Mengenai ini, seorang hamba dianjurkan untuk meresapi makna-makna agar dapat malakukan tindakan secara benar. Inilah yang dimaksud dengan yakin beriman kepada Allah dengan tindakan. Adapun yakin beriman kepada Allah dengan ucapan dapat dilakukan dengan mengumpulkanya, menghafalnya, serta berdoa menggunakan nama-nama-Nya (Syadzi, 2012). Selain itu iman kepada Allah adalah membenarkan dengan hati bahwa Allah itu benar-benar ada dengan segala sifat keagungan dan kesempurnaanNya, kemudian pengakuan itu diikrarkan dengan lisan, serta dibuktikan dengan amal perbuatan secara nyata (Muhayati, Christiana, Trisnani, 2015).

Yakin Bahwa Allah Memiliki Malaikat yang Tugasnya Berhubungan dengan Manusia: Kewajiban sebagai Muslim meyakini bahwasanya ada diantara para malaikat yang bertugas muqarrabun (yang didekatkan pada-Nya) seperti malaikat Jibril, Mikail, dan Israfil. Sebagaimana yang pernah disampaikan oleh al-Jazairi (2015): (1) Sampainya wahyu ilahi kepada para nabi dan para rasul, Sebab sampainya wahyu kepada mereka dengan perantara Ar-Rubul Al-Amin, yaitu Jibril yaitu malaikat yang bertugas yang menyampaikan wahyu. (2) Kematian manusia karna ruhnya dicabut, merupakan bukti eksistensi malaikat maut. (3) Terjaganya manusia dari gangguan dan kejahatan Jin dan setan sepanjang hidupnya, padahal mereka hidup disekelilingnya dan mereka dapat melihatnya. Jin dan setan dapat melihat dan menyakiti manusia dan manusia tidak dapat melihatnya dan menyakitinya. Itu bukti bahwa adanya malaikat yang mejaga manusia.

Hal ini membuktikan bahwa orang yang beriman kepada malaikat Allah, maka individu tersebut akan lebih berhati-hati dalam menjalankan kehidupannya, karena selalu mengingat bahwa terdapat dua malaikat yang mengikutinya (Nuryati, 2018). Adapun dengan yakin dengan keimanan kepada malaikat membawa implikasi dan efek ruhaniah yang dapat mempengaruhi moral dan perilaku manusia. Dengan kata lain, keimanan kepada malaikat memiliki nilai-nilai edukatif yang tentunya sangat urgen untuk diaplikasikan dan merupakan acuan dasar dalam proses pendidikan agama termasuk di dalamnya konseling agama ataupun konseling Islam (Harisah, 2004).

Yakin bahwa Allah menurunkan Kitab Suci Al-Quran untuk pedoman hidup bagi manusia. Adanya firman-Nya pada Al-Quran merupakan bukti atas wujud Allah, karena sangat mustahil ada pembicaraan tanpa adanya pembicara 
Implementasi Prinsip Yakin pada Rukun Iman dalam Konseling Islam atau adanya ucapan tanpa ada yang mengucapkan. Al-Quran sebagai kitab suci adalah kebenaran yang bersifat mutlak yang mengandung panduan hidup bagi manusia, juga pedoman bagi setiap pribadi dan undang-undang bagi seluruh manusia. Iman kepada kitab Allah berarti mempercayai bahwa Allah telah menurunkan kitab suci melalui rasul-rasul-Nya sebagai pedoman dalam kehidupan manusia, yang salah satunya adalah kitab al-Qur'an. Al-Qur'an adalah panduan hidup bagi semua orang, tidak terkecuali orang-orang non muslim (Nuryati, 2018).

Petunjuk perawatan jasmani, rohani dan iman manusia itu ada dalam Kitab Suci al-Quran. Ia bukan hasil pemikiran manusia dan bukan pula hasil penelitian manusia yang memiliki kemungkinan salah, ia diturunkan dari Dzat yang Maha Menciptakan manusia yang memiliki tingkat kebenaran mutlak yang tiada keraguan sedikitpun. Sebagaimana firman Allah yang artinya: Artinya:'Dan Sesunggubnya Al-Quran Ini benar-benar diturunkan oleb Tuban semesta Alam, ia dibawa turun oleb Ar-Rub Al-Amin (Jibril), ke dalam hatimu (Mubammad) agar kamu menjadi salah seorang di antara orang-orang yang memberi peringatan, dengan bahasa Arab yang jelas. Dan Sesunggubnya Al Qur'an itu benar-benar (tersebut) dalam kitab-kitab orang yang dabulu” (Asy-Syu'ara':192-196).

Yakin Bahwa Allah Mengutus Para Rasul untuk Membimbing Manusia.: Pada umumnya, keyakinan seorang hamba akan berkembang sejalan dengan terjadinya peristiwa-peristiwa yang sesuai dengan prediksi Rasulullah, atau dengan mukjizat Rasulullah satu persatu sehingga mampu membanggun keyakinan sedikit demi sedikit. Dengan kata lain, terbentuknya keyakinan ini merupakan hasil kumulatif. Seseorang yang menyakini bahwa Nabi Muhammad adalah utusan Allah serta mengamalkan apa yang diamalkan oleh Rasulullah maka di dalam dirinya akan dihadirkan perasaan tenang dan nyaman dalam menghadapi problem kehidupan (Nuryati, 2018).

Oleh karena para rasul itu adalah perantara Allah sang Pencipta dengan hamba-hamba-Nya, sedangkan para rasul adalah manusia sama seperti manusia pada umumnya yang hidup dalam batas waktu tertentu, lalu mereka wafat maka dari itu risalah mereka bawa termuat dalam kitab-kitab khusus, sehingga ajaran dan misi yang mereka bawa itu tidak sirna bersamanya. Sebagaimana firman Allah SWT yang artinya: Artinya: "Hai abli kitab, Sesunggubnya Telab datang kepadamu Rasul kami, menjelaskan kepadamu banyak dari isi Al Kitab yang kamu sembunyi kan, dan banyak (pula yang) dibiarkannya. Sesunggubnya Telah datang kepadamu cahaya dari Allah, dan Kitab yang menerangkean. Dengan Kitab Itulah Allab menunjuki orang-orang yang mengikuti keredhaan-Nya ke jalan keselamatan, dan (dengan Kitab itu pula) Allah mengeluarkan orang-orang itu dari gelap gulita kepada cabaya yang terang benderang dengan seizin-Nya, dan menunjuki mereka ke jalan yang lurus.” (Q.S. Al-Ma'idah:15-16).

Yakin bahwa hari kiamat akan terjadi. Nuryati (2018) menyebutkan bahwa seorang yang beriman kepada hari akhir berarti individu tersebut percaya akan ada 
Jarnawi., Azhari., A, Urka.

pergantian alam dunia menuju alam akhirat. Shihab (2002) menunjukkan bahwa keyakinan tentang datangnya hari kiamat mengantarkan manusia untuk melakukan aktivitas-aktivitas positif dalam kehidupannya, walau'pun aktivitas itu tidak mendatangkan keuntungan materi dalam kahidupan dunianya. Dengan keyakinan tentang datangnya hari kiamat mendorong individu memiliki kontrol diri yang baik, yang timbul dari kesadaran diri bahwa apa pun yang ia lakukan pasti akan mendapat balasan dari Allah. Jika seseorang telah memiliki kontrol diri yang baik, mereka akan besikap dengan dilandasi akal sehatnya. Beriman kepada hari kiamat juga bagian dari terapi diri" diaman kecewa di dunia akan ada pengadilan dari yang Maha adil di akhirat nanti. Seseorang bisa lepas dari tuntutan pengadilan dunia, tetapi meraka tidak akan mampu lari dari pengadilan Illahi. Keyakinan inilah yang memperkuat hati mereka hingga tumbuh dalam dirinya ridha dan berserah diri.

Yakin bahwa ada takdir atau ehendak Allah mengandung makna bahwa ada ketentuan Allah yang pasti berlaku untuk setiap makhluk-Nya dan apa yang telah diupayakan individu bisa terwujud semata-mata atas izin Allah (Nuryati, 2018). Seorang Muslim beriman kepada qada dan qadar Allah, kebijaksanaan dan kehendak-Nya: beriman bahwasanya tidak ada sesuatu pun yang terjadi di dalam wujud ini, hingga perbuatan manusia yang ikhtiyari (pilihan) melainkan didahului oleh Allah dan takdirnya dan beriman bahwasanya Allah maha adil dalam qada dan qadar-Nya dan kebijaksanaanya itu tergantung kepada masyiah (kehendak) Nya. Maka apa saja yang Dia kehendaki pasti akan terjadi, dan apa yang saja yang tidak dikehendaki-Nya tidak akan terjadi, dan tiada daya dan tiada pula kekuatan melainkan pertolongan dari-Nya. Sebagaimana firman Allah yang artinya "Tidak ada suatu musibah pun yang menimpa seseorang kecuali dengan ijin Allah; dan barangsiapa yang beriman kepada Allah niscaya dia akan memberi petunjuk kepada hatinya. Dan Allah Maha mengetahui segala sesuatu."(Q.S. At-Taghabun: 11). Selain itu, Rasulullah di dalam hadisnya mengabarkan kita wajib beriman dengan adanya taqdir tetapi juga harus berusaha, maka beralasan dengan qada dan qadar sama sekali bukan udzur untuk beramal dan berusaha dalam kehidupan (Sulidar, Ardiansyah dan Prabowo, 2017).

\section{PENUTUP}

Berdasarkan dari temuan dan pembahasan hasil penelitian, maka dapat ditarik kesimpulan yaitu sebagai berikut: Implementasi prinsi yakin dalam Islam ialah bagaimana menerapkan prinsip yakin yang kokoh sehingga dapat mendalami makna yakin dengan seutuhnya ajaran Islam. Perintah Allah kepada hambahambannya untuk beriman dan yakin pada ketetapan dari-Nya. Dengan dorongan akan adanya pemberian balasan yang sesuai dengan apa yang telah dilakukan. Jalan menuju yakin, yaitu berkontemplasi (Merenung), mentadaburi Al-Quran, berdoa dan khalwat. Hakikatnya dari prinsip yakin dalam Islam adalah agar individu dapat 
Implementasi Prinsip Yakin pada Rukun Iman dalam Konseling Islam meraih ilmul yakin, ainul yakin atau haqqul yakin untuk menentukan pandangan dan jalan hidupnya sendiri berdasarkan tingkatan yang diraih dengan pertimbangan akal sehat dan secara jujur tentang apa yang benar-benar salah, antara mana yang baik-buruk dan akan selalu tampil sebagai seorang yang berani, penuh percaya diri, dan berkepribadian kuat.

Implementasi prinsip yakin pada rukun iman dalam konseling Islam, di mana konselor Islam harus mendalami konsep prinsip yakin pada rukun iman yang terkandung dalam surat Al-Quraisy ayat ke 4, surat As-Syuara' ayat ke 78-81 dan surat Al-Anam ayat ke 82 agar dapat mewarnai konseli secara keseluruhan dengan warna Islam, karena yakin dalam ajaran Islam tidak sama dengan dogma atau persangkaan tetapi harus melalui ilmu, pemahaman dan kesaksian. Seluruh kehidupan Muslim berpusat dan dibentuk oleh-Nya, Dialah yang memberi manusia makan agar tidak lapar dan Dialah yang telah memberikan keamanan dan banyak kemurahan kepada semua manusia.

Maka hendaklah manusia beribadah kepada Allah dengan mengesakan-Nya tidak menyekutukan-Nya dengan sesuatu apapun, yakin bahwa Allah memiliki malaikat yang tugasnya berhubungan dengan manusia, yakin bahwa Allah menurunkan kitab suci Al-Quran untuk pedoman hidup bagi manusia, yakin bahwa Allah mengutus para rasul untuk membimbing manusia, yakin bahwa hari kiamat akan terjadi dan yakin bahwa ada takdir atau kehendak Allah. Maka kedua kenikmatan dalam ayat ini, kesejahteraan ekonomi dan stabilitas keamanan merupakan tanda-tanda dari orang yakin kepada rukun iman dengan cara bergaul dengan orang saleh, perilakunya lebih baik dari sebelumnya, berhenti dari perbuatan dosa dan menerima dengan tangan terbuka terhadap segala kebajikan, selalu cemas terhadap azab dan murka Allah. Dengan ia selalu diliputi rasa cemas terhadap murka-Nya, hatinya berpaling dari hal-hal keduniaan, sebaliknya hati itu haus akan hal-hal yang bersifat ukhrawi, hatinya selalu aktif, tersadar karena penyesalan dan rasa cemas yang terus membayangi.

Untuk menyadarkan diri klien mengenai potensi dirinya dan meningkatkan kesadaran beriman klien. Bentuk dan jenis bantuan yang dapat dilakukan atau diberikan konselor kepada klien untuk mengakui keberadaan Allah, dan tunduk kepada-Nya melalui sabar apabila mendapat cobaan, bertawakal secara keseluruhan, ridha dan takwa pada segala ketetapa-Nya. Dengan meningkat keyakinannya yaitu melalui terapi, adapun bantuan yang dapat diberikan untuk meningkatkan keyakinan pada rukun iman konseli ialah dengan memberikan pemahaman. Di antaranya sebagai berikut: pertama, menanamkan keimanan dengan akidah ketauhidan dalam jiwa klien dan menumbuhkan bibit-bibit ketakwaan dalam hati klien. Kedua, mewajibkan kepada klien beraneka ragam bentuk ibadah. Ketiga, terapi sabar, membiasakan diri dalam berzikir, beristighfar dan bertawakal kepada Allah. Keempat, menggunakan metode yang beragam dalam memperbaiki perilaku yang menyimpang seperti halnya dengan konsep 
Jarnawi., Azhari., A, Urka.

yang bertahap, konsep rayuan, ancaman dan konsep kisah dan banyak lainnya.

Oleh karena itu konselor perlu memberikan pelayanan konseling islami guna membantu konseli memperkuat keimananya dan membuat konseli yakin bahwa Allah S.W.T. selalu membantu disetiap permasalahannya. Agar dengan keadaan hidup yang serba terpenuhi, konselor akan membimbing konseli untuk memperoleh kedamaian, ketenangan, dan ketentraman baik di dunia maupun di akhirat kelak.

\section{DAFTAR PUSTAKA}

Abdurrahman, A. (2019). Fungsi dan Peran Konseling Islam Dalam Pendidikan. Islamic Counseling : Jurnal Bimbingan dan Konseling Islam

Al-Ghazali, I. (2017). Minhajul Abidin, Penj. Abu Hamas As-Sasaky, Jakarta: Khatulistiwa Press.

Al-Jaza'iri, A. B. J. (2015). Minhajul Muslim. Jakarta: Darul Haq.

Diniaty, A. (2013). Urgensi Teori Konseling dan Perspektifnya dalam Islam Menjawab Tuntutan Konseling Religius di Masa Depan. Jurnal Al-Ta'lim 1(4).

Harisah, A. (2004). Keberimanan Kepada Malaikat dalam Perspektif Pendidikan Islam. Kependidikan Islam 2(1)

Ilmi, N. (2012). Buku Induk Terlengkap Agama Islam. Yogyakarta: Citra Risalah, 2012.

Kamaruzzaman, K. (2014). Model bimbingan kelompok berbasis rukun iman untuk mencegah kenakalan remaja, Sosial Horizon: Jurnal Pendidikan Sosial $1(1)$.

Khirzani, N., Effendi, D.I., dan Mujib, A. (2019). Bimbingan Agama dalam Meningkatkan Pemahaman Ketauhidan Remaja. Irsyad: Jurnal Bimbingan, Penyuluban, Konseling, dan Psikoterapi Islam 7(3).

Muhayati, S., Christiana, R., dan Trisnani, R.P. (2015). Iman Kepada Allah dan Perhatian Orang Tua terhadap Budaya Nyontek Anak Usia Sekolah Dasar. Counsellia: Jurnal Bimbingan dan Konseling.

Mujieb, M.A. (2009). Ensiklopedia Tasawuf Imam Al-Ghazali, Jakarta: Mizan Publika. Mulyadi. (2016). Bimbingan dan Konseling di Sekolah dan Madrasah. Jakarta Kencana.

Nuryati, N. (2018). Bimbingan Rohani Islam Dan Perasaan Tenang Lansia (Study Kasus Lansia PKH Kecamatan Trucuk Klaten), Hisbah: Jurnal Bimbingan Konseling dan Dakwah Islam 15(1).

Prayetno, P. dan Emran, A. (2004). Dasar-Dasar Bimbingan Dan Konseing, Jakarta: Rinika Cipta.

Shihab, M. Q. (2002). Tafsir al-Misbah: Kesandan Keserasian Al-Quran. Jakarta: Lentera Hati.

Siregar, R. (2015). Pengembangan Fitrah Manusia melalui Konseling Islam. Fitrah 1(1).

Irsyad : Jurnal Bimbingan, Penyuluhan, Konseling, dan Psikoterapi Islam 08(3) (2020) 251-266 
Implementasi Prinsip Yakin pada Rukun Iman dalam Konseling Islam

Sulidar, S., Ardiansyah, A., dan Prabowo, Y. (2017). Wawasan tentang Taqdir dalam Hadis. AT-TAHDIS: Journal of Hadith Studies 1(2).

Sutoyo, A. (2014). Keyakinan, Manusia Dalam Persfektif Al-Qur'an, Yogyakarta: Pustaka Pelajar.

Sutoyo, A. (2017). Peran Iman dalam Pengembangan Pribadi Konselor yang Efektif. Jurnal Psikoedukasi dan Konseling 1(1).

Syadzi, K.A. (2012). Yakin Agar Hati Selalu Yakin, Jakarta: Amzah.

Willis, S. S. (2009). Konseling Individual Teoridan Praktek. Bandung: Alfabeta.

Yusuf, M. J. (2012). Model Konseling Islami, Banda Aceh: Lembaga Naskah Aceh NASA.

Zulfa, N. (2017). Nilai-nilai dan makna bimbingan konseling Islam dalam Hadis Sahīh Bukhārī (studi hadis tentang rukun islam), Religia, 20(2). 
Jarnawi., Azhari., A, Urka. 